Warszawskie Studia Pastoralne UKSW

Rok X 2015 Nr 4 (29)

Aldona Maria Piwko

\title{
KOBIETA W ISLAMIE. MUZUŁMAŃSKI FEMINIZM?
}

\author{
Woman in islam. Islamic feminism?
}

Kobieta $\mathrm{w}$ tradycji islamu pozostaje od wielu lat nieustającym tematem zainteresowania, w wielu aspektach: jej miejsce w rodzinie, status w społeczności wierzących oraz możliwość własnego rozwoju osobistego, na podstawowych płaszczyznach życiowych - duchowej, intelektualnej i emocjonalnej. Sytuacja muzułmańskiej kobiety jest niewątpliwie, jednym ze szczególnie popularnych tematów, podejmowanych w literaturze i mediach oraz dyskusji politycznej. Zastanawiać by się można dlaczego tak się dzieje, skoro kobiety stanowią blisko 48\% ludności całego świata, największe zainteresowanie skierowane jest na kobiety wyznajace islam. Opinia publiczna niemal całego świata, w sposób szczególny zaczęła interesować się kobietami wierzącymi w Allaha, po zamachach na World Trade Center w Nowym Jorku we wrześniu 2001 roku. Konsekwencją tych wydarzeń było rozpoczęcie wojny z terroryzmem i wkroczenie wojsk NATO do Afganistanu. Wówczas światowe media zainteresowały się tragiczną sytuacją afgańskich kobiet, dokładnie przykrytych burką żyjących w cieniu męskiego świata.

Jednakże wbrew powszechnej opinii, status kobiety w islamie jest wysoki. Owszem wiele zalecanych zachowań, nakazów i zakazów

1 Burka pełna, zwana także burką afgańską jest strojem całościowym, dokładnie zakrywającym całe ciało kobiety. W miejscu oczu jest gęsta siateczka, która co prawda umożliwia patrzenie kobiecie na otaczający ją świat, ale przez fakturę materiału. $\mathrm{Z}$ tego powodu burka stała się symbolem zniewolenia muzułmańskich kobiet i jest utożsamiana z reżimem koranicznym. 
wynika bezpośrednio z praktykowanej religii, którym wierzące niewiasty dobrowolnie się poddają, ponieważ tak zostały wychowane, a także dlatego, że nie znają innych wzorów postępowań. Miejsce kobiety muzułmanki w społeczności wierzących w Allaha, jest w znaczącym stopniu uzależnione od religii, jej zasad oraz praktyk związanych $\mathrm{z}$ wypełnianiem bożych zaleceń. Kobiety w różnych częściach świata muzułmańskiego, posiadją rozmaite przywileje i wolności. O liberalizujących się zwyczajach oraz zmianach w świadomości społeczeństwa, świadczą kobiety walczące po stronie samozwańczego Państwa Islamskiego. Muzułmankom nie obcy jest także ruch społeczny, zwany feminizmem.

\section{Muzułmanki w historii}

W okresie przedmuzułmańskim kobieta była uprzedmiotowiona. Dominujący na Półwyspie Arabskim styl rodziny patriarchalnej ${ }^{2}$ powodował, że kobiety nie posiadały praktycznie żadnych praw. Całkowicie uzależnione od ojca, braci lub męża musiały pokornie przyjmować ich decyzje. W społeczeństwie patriarchalnym obowiązywało wyraźne rozróżnienie pozycji kobiet, dzieci i mężczyzn od szczególnej pozycji ojca-seniora, będącego głową oraz opiekunem rodu. Ponadto dorosłemu mężczyźnie należny był szacunek pozostałych domowników, wynikający z istotnej funkcji jaką pełnił w rodzinie. Obowiązek zapewnienia środków materialnych na utrzymanie domu, a także odpowiedzialność za bezpieczeństwo najbliższych krewnych, zwłaszcza kobiet i dzieci, stanowiły podstawowe zadania do wypełnienia. Na terenach zdominowanych przez patriarchalizm codziennością było traktowanie kobiety jak niewolnicy, całkowicie uzależnionej najpierw od ojca, a później od męża. Z tego względu kobieta nie mogła posiadać własności, co nierozerwalnie łączyło się $\mathrm{z}$ brakiem prawa dziedziczenia.

Do czasów nastania islamu, powszechny był zwyczaj wad, czyli grzebania nowonarodzonej dziewczynki żywcem, zazwyczaj uważanej

2 Patriarchalizm jest pojęciem socjologicznym, oznaczającym dominację mężczyzny zarówno w stosunkach rodzinnych, jak i społecznych. 
za upokorzenie dla rodziny. Owo barbarzyńskie postępowanie pochodzi z tradycji starożytnego Wschodu. Czyniono tak bowiem uważano, że synowie są wartością dla wzmocnienia plemienia lub całego klany, zaś wraz z kolejną córką, powstają nowe problemy dla rodziny ${ }^{3}$. W Koranie zostało napisane: „A kiedy zwiastują któremuś z nich córkę, to jego oblicze się zasępia i jest udręczony" $(16,58)^{4}$. Konieczne zatem było jej pilnowanie i dbanie o ochronę jej moralności, ponieważ niewłaściwe etycznie zachowanie córki, przynosiło hańbę całej rodzinie. Powszechność zwyczaju wad miało istotne znaczenie na późniejsze traktowanie kobiety, w jej życiu dorosłym. Społeczeństwo postrzegało ją jak rzecz i obiekt pożądań, którą w każdej chwili można odrzucić, bez ponoszenia konsekwencji ${ }^{5}$. Kobieta w społeczności arabskiej czasów przedmuzułmańskich, miała pozostawać całkowicie posłuszna swojemu ojcu lub męskiemu opiekunowi, musiała wyjść za mąż, zgodnie z umową zawartą przez ojca. Uprzedmiotowienie kobiety dostrzegalne było w wielu aspektach życia. Prawny „właściciel" kobiety, a więc w pierwszej kolejności ojciec, a następnie mąż, mógł ją wymienić na inną - siostrę lub matkę. Zdarzało się także odsyłanie kobiety do innego, obcego mężczyzny, aby w ten sposób otrzymać zdrowego i silnego potomka. Zatem misją kobiety Półwyspu Arabskiego w czasach dżahiliji ${ }^{6}$ było małżeństwo oraz wydanie na świat zdrowych synów.

Owszem w niektórych plemionach berberskich oraz beduińskich, kobiety zajmowały znaczące stanowiska w strukturze klanowej. Było to powodowane znajomością przez nie rozmaitych praktyk magicznych, mogących poprowadzić wspólnotę plemienną do dobrobytu. Zazwyczaj kobiety te posiadały dar jasnowidzenia lub przepowiadania

${ }^{3}$ Do dziś ze zbliżonymi problemami dotyczącymi rodzących się córek, borykają się mocno związane z tradycją przodków, hinduskie rodziny. Każda kobieta w rodzinie przynosi ze sobą kłopoty dla ojca lub opiekuna.

4 Wszystkie odwołania do Koranu pochodzą z wydania: Koran z języka arabskiego przełożył i komentarzem opatrzył Józef Bielawski, Warszawa 2007.

5 Por. E. Machut-Mendecka, Świat tradycji arabskiej, Warszawa 2005, s. 103.

${ }^{6}$ Dżahilija - czas niewiedzy, ciemności, nieświadomości. W tradycji muzułmańskiej, określenie to odnosi się do czasów przed nastaniem islamu. 
przyszłości. Do takiej grupy kobiet należały: Al-Jamama az-Zarqa posiadająca dar widzenia przyszłości. Zapowiedziała zbliżających się wrogów, jednak nikt jej nie uwierzył, w wyniku czego plemię zostało zabite przez najeźdźców. Dziś Al-Jamama az-Zarqa jest symbolem przestróg. Podobnie „Prorokini” berberska, pochodząca z Algierii Al-Kahina, dzięki jej staraniom zrzeszyły się plemiona berberskie i mogły odeprzeć zagrożenie podboju muzułmańskiego w VII wieku? Jednak takie postrzeganie kobiety należało do rzadkości. Znacznie częściej była obiektem seksualnym i rzeczą.

Islam zniósł wiele pogańskich zwyczajów, powszechnych w okresie dżahiliji na terenach Półwyspu Arabskiego, stając się religią państwa i prawa, a tym samym znacząco odmienił pozycję kobiety w społeczeństwie oraz jej postrzeganie przez współbraci w wierze. Muzułmanka od samego początku konstytuowania się islamu, zajmowała istotne miejsce w społeczności, bowiem miała do wypełnienia istotne zadanie. Koran nadał kobietom równe prawa z mężczyznami: „Ktokolwiek pełni dobre dzieła, mężczyzna czy kobieta i jest wierzącym, tacy wejdą do Ogrodu i nie doznają niesprawiedliwości" $(4,124)$. Zagwarantował tym samym równouprawnienie kobietom muzułmańskim, nakładając na nie takie same obowiązki wobec Boga jakie posiadali mężczyźni, zakazując jednocześnie jakiejkolwiek formy dyskryminacji ze względu na płeć. Potwierdzają to słowa Koranu: „Zaprawdę - muzułmanie i muzułmanki, wierzący i wierzące, prawdomówni i prawdomówne, cierpliwi i cierpliwe, pokorni i pokorne (...), wspominający Boga często i wspominające - przygotował dla was Bóg przebaczenie i nagrodę ogromną" $(33,35)$. Kobieta zyskała tym samym możliwość praktykowania religii, na równi z mężczyznami, będąc jednocześnie samodzielnie odpowiedzialna przed Bogiem za swoje postępowanie i życie zgodne z Jego nakazami.

Nadanie znaczących praw społecznych kobiecie w tradycji islamu, umożliwiło jej wymaganie należnego szacunku, a także ochrony ze

${ }^{7}$ Por. E. Machut-Mendecka, Kobieta bez zasłony. Muzułmanka w świetle wiary i kultury, w: Być kobietą w Oriencie, red. D. Chmielowska, B. Grabowska, Warszawa 2008, s. 20. 
strony męskich członków rodziny. Owa ochrona polegała nie tylko na zapewnieniu podstawowych potrzeb życiowych, lecz również dotyczyła jej godności i czci. Ponadto męska opieka nad kobietą dotyczyła także jej zabezpieczenia materialnego, tym samym kobiety muzułmańskie zyskały prawo do posiadania własności oraz dziedziczenia ${ }^{8}$.

Zrównując status kobiety i mężczyzny, islam zniósł zwyczaj wad, podkreślając boskie pochodzenie kobiety w następujących słowach: „Oni przypisują Bogu córki, niech Mu będzie chwała! A oni mają to, czego pragną. A kiedy zwiastują któremuś z nich córkę, to jego oblicze się zasępia i jest udręczony. On ukrywa się przed ludźmi z powodu tego nieszczęścia, które mu obwieszczono: czy on ma je zachować, mimo poniżenia, czy też grzebać je w prochu. Jakże źle oni rozumują!” (16,57-59). Tym samym prawo wywodzące się z religii, nadało kobiecie takie same prawa osobowe, co mężczyźnie. Uznanie równości kobiety i mężczyzny wobec Boga jest nadrzędnym prawem ludzkim. Jednakże każde z nich, tak kobieta jak i mężczyzna, posiadają odrębne oraz różne role społeczne, które winni wykonywać należycie, a także zgodnie z naturalnym, a więc Boskim powołaniem.

Przykładem zmian w mentalności członków ummy jest uczestniczenie pierwszych muzułmanek w wielu aspektach życia społecznego. Chadidża, żona Mahometa, była kobietą interesu, zajmującą się handlem. Prowadziła własną działalność gospodarczą, dziś nazwalibyśmy ją bizneswoman, kierowała także pracującymi dla niej mężczyznami, a przy tym była osobą religijną. Uważana jest za pierwsza osobę, która uwierzyła w posłannictwo Mahometa i słowa, które do niego skierował archanioł Gabriel, stając się tym samym pierwszą muzułmanką. Chadidża jest wymieniana pośród czterech szlachetnych kobiet $^{9}$ islamu, bowiem była wsparciem dla swojego męża, pomagając mu zaakceptować ciężar proroctwa i odpowiedzialności jaką nałożył na niego Bóg ${ }^{10}$.

8 Por. M. Gaudefroy-Demombynes, Narodziny islamu, Warszawa 1988, s. 449-453.

9 Oprócz Chadidży są to także: Asija, żona faraona, która wychowywała Mojżesza, Maryja matka Jezusa oraz córka Mahometa Fatima.

10 Por. S. H. Nasr, Ideei wartości islamu, Warszawa 1988, s. 71. 
Także pozostałe żony Mahometa są wzorem dla wielu współczesnych muzułmanek, bowiem swoją postawą, w czasach trudnych dla społeczności islamu, dawały przykład tego, jak należy postępować, aby cała wspólnota stawała się jednością. Należy zauważyć, że żony Mahometa $\mathrm{z}$ okresu medyńskiego wykazywały aktywne zaangażowanie w działalność na rzecz ummy. Były opiekunkami i wychowawczyniami młodego pokolenia, jak Sauda Bint Zama’a, brały udział w bitwach jak chociażby A'isza. Ponadto najmłodsza z żon proroka była osobą bardzo inteligentną, o doskonałej pamięci, co zaowocowało znaczącą liczbą hadisów autorstwa A’iszy. Zajnab Bint Chuzajma spełniała się jako pielęgniarka i osoba oddana potrzebującym, zyskując przydomek Matka nieszczęśliwych. Jej pomoc bliźnim była zapewne spowodowana własnymi przeżyciami, bowiem mąż Zajnab zginął w bitwie pod Uhudem ${ }^{11}$.

Oprócz kobiet znanych z tradycji koranicznej, w ciągu czternastu wieków historii islamu było wiele niewiast, które wyraźnie zaznaczyły swoją obecność w kształtowaniu się tradycji muzułmańskiej $\mathrm{w}$ różnych zakątkach świata. Zapisały się one w historii islamu w rozmaitych dziedzinach, nie zawsze typowych dla kobiet, jak chociażby w pracach dobroczynnych, nauce, również w teologii, a także w sztuce wojennej i dyplomacji. Do dziś cenionym przez muzułmanów komentarzem do Sunny Mahometa, jest publikacja Karimy bint Ahmad al-Maruzyji ${ }^{12}$. Podobnie Hafsa bint Syrii, specjalizowała się w teologii muzułmańskiej, znała Koran na pamięć. Również Fatami bint al-Abbas odznaczała się wiedzą religijną, nazywano ją muftiją, a więc uczoną, wydającą opinie prawne. Z kolei Fatami bint Muhammad al-Finari była fundatorką meczetu w marokańskim Fezie. Pełnił on także funkcje edukacyjne, społeczne i polityczne, przekształcając się w uniwersytet, obecnie uważany za najstarszy na świecie. Ponadto na przestrzeni wieków było wiele uczonych kobiet, które kształciły się zdobywając tytuły naukowe, przyczyniając się do rozwoju nauk

\footnotetext{
11 Por. M. Gaudefroy - Demombynes, Narodziny..., dz. cyt., s. 178-182.

12 Por. J. Heath, The Scimitar and the Veil: Extraordinary Women of Islam, Mahwah 2004, s. 146-147.
} 
humanistycznych oraz matematycznych ${ }^{13}$. Przykłady kobiet w historii islamu, posiadają niewątpliwie istotne znaczenie dla kształtowania postawy muzułmańskich kobiet współcześnie. Stanowią bowiem wzór do naśladowania oraz zachętę do podejmowania nowych wyzwań.

\section{Powinności kobiety wg zasad islamu}

Intensywna ekspansja ${ }^{14}$ islamu spowodowała wymieszanie praw wywodzących się z pierwotnej koncepcji religijnej z obyczajami panującymi na terenach podbitych. Konsekwencją tego było, istotne dla późniejszego statusu kobiety, powolne zanikanie praw należnych muzułmankom, nadanych przez Mahometa. Tym samym pozycja kobiety ulegała powolnej degradacji. Koniecznym było przywrócenie pierwotnego stanu, co nie zawsze jest właściwie rozumiane przez tradycję łacińską.

Zgodnie z nauką islamu, kobieta jest przede wszystkim powołana do tego, aby być żoną i matką. Jest to nierozerwalnie związane z patriarchalnym systemem społecznym, obowiązującym na terenach Arabii, a zarazem organizującym życie wspólnoty muzułmańskiej. Mężczyzna był odpowiedzialny za zapewnienie bytu materialnego swojej rodzinie, aby kobieta mogła w poczuciu bezpieczeństwa i wygody, wychować młode pokolenie muzułmanów. W związku z tą szczególną funkcją, którą pełni w społeczeństwie, islam postawił kobiecie wysokie wymagania, zwłaszcza w sferze moralności. Kobieta w sposób szczególny jest predestynowana do tego aby być przede wszystkim matką, zaś jako ta, która przekazuje życie, ma stanowić wzór dla swoich dzieci, a tym samym przyczyniać się do kształtowania właściwych postaw przyszłych pokoleń wierzących. Jednym z celów małżeństwa jest przekazanie życia, dlatego od muzułmańskiej żony oczekuje się aby była zdolna do macierzyństwa. Nie oznacza to jednak, że islam zabrania wstępowania w związki małżeńskie lub odrzuca na margines społeczeństwa kobiety bezpłodne. Niemniej jednak kobieta w ciąży cieszy się większymi

\footnotetext{
13 Por. H. Abu-Rub, B. Zabża, Status kobiety w islamie, Wrocław 2002, s. 236-239.

14 Można wyróżnić dwa główne etapy ekspansji islamu w historii: VII-VIII wiek (konsekwencją był największy rozkwit oraz szczyt cywilizacji muzułmańskiej w wiekach X-XII) oraz XIV-XV wiek związane z podbojami tureckimi.
} 
prawami oraz podlega specjalnej ochronie. Ze względu na swój stan oraz konieczność zadbania o zdrowie i prawidłowy rozwój nienarodzonego dziecka, nie ma ona obowiązku poszczenia w dni nakazane prawem oraz uczestniczenia w modlitwie piątkowej ${ }^{15}$.

Inną cechą żony jest posłuszeństwo. Kobieta winna być posłuszna mężowi we wszystkich kwestiach, pod warunkiem, że są one zgodne z zasadami islamu. Dotyczy to także uległości w stosunkach seksualnych, ponieważ islam zobowiązał kobiety do zaspokajania potrzeb seksualnych męża. Zwolniona zostaje z obowiązku posłuszeństwa, gdy mężczyzna oczekuje od niej czegoś, co jest sprzeczne z prawem Allaha. Żona ma być czuła, a także kochająca wobec męża, a stosując w swoim życiu słowa Koranu: „Niech będa pobłażliwi i wybaczajacy! Czyż nie pragniecie, by Bóg wam przebaczyt?” $(24,22)$ powinna odznaczać się tolerancją i z łatwością wybaczać mężowi drobne błędy ${ }^{16}$. Jednocześnie kobieta ma prawo oczekiwać od męża uwagi oraz wspólnego spędzania czasu tak, aby móc pielęgnować więzi małżeńskie, wzmacniając tym samym związek dwojga ludzi. Zgodnie z tradycją muzułmańską, to mężczyzna zapewnia stabilność finansową domu. Żona zaś zobowiązana jest do dbania o interesy oraz majątek męża. Może korzystać ze wspólnego majątku bez jego wiedzy. Nie powinna jednak być przesadnie rozrzutna, mając na uwadze, jak wiele wysiłku wymaga ich zarobienie. Troska kobiety o swego męża przejawia się także w codziennych czynnościach, ujawnianych w dbaniu o zwykłe potrzeby, do których niewątpliwie należą: przygotowanie posiłku, zapewnienie czystego ubrania, sprzątanie mieszkania. Jeśli jednak kobieta nie była przyzwyczajona do takich czynności w domu rodzinnym i ich nie wykonywała, mężczyzna nie może jej do nich zmuszać. Wówczas musi zapewnić żonie odpowiednią pomoc domową. Mężczyzna jest głową rodziny, ale sprawnym funkcjonowaniem domu zarządza kobieta. Żona w tradycji muzułmańskiej zobowiązana jest by trwać przy mężu i służyć mu radą. Jej wsparcie szczególnie w trudnych chwilach oznacza troskę o spokój psychiczny małżonka.

15 Por. H. Abu-Rub, B. Zabża, Status..., dz. cyt., s. 47.

16 Por. M. Zyzik, Małżństwo w prawie muzułmańskim, Warszawa 2003, s. 39. 
Zgodnie ze zwyczajami obowiązującymi w tradycji islamu, kobieta wstępująca w związek małżeński nie zmienia swojego rodowego nazwiska na nazwisko męża. ${ }^{17}$ Ponadto wbrew powszechnej opinii, nie staje się własnością mężczyzny, zachowuje pełnię swobód, do których należą przede wszystkim wizyty w domu rodzinnym oraz pozostanie przy własnej religii i jej praktykowanie. Uczeni podkreślają, że tylko wspólne podejmowanie decyzji w małżeństwie, przyczynia się do harmonii oraz szczęścia rodzinnego. Owszem mężczyzna jest przewodnikiem w rodzinie, jednakże nie oznacza to, że jest władcą absolutnym.

Wykazano wcześniej, że muzułmanki w historii były kobietami wykształconymi, dążącymi do pogłębiania swojej wiedzy. Dlatego też kobieta ma prawo do kształcenia się, zgodnie z własnymi zainteresowaniami oraz na każdym etapie: podstawowym, średnim oraz wyższym. To mężczyzna, przede wszystkim ojciec, a następnie mąż ma obowiązek zapewnić kobiecie właściwy poziom edukacji, jeśli ona tego pragnie. Uczony Ibn al-Hadżdż, podkreśla, że: „Jeżeli kobieta domaga się od swego męża praw do religijnego wykształcenia i przedkłada ten spór na ręce sędziego, jest ona usprawiedliwiona w żadaniu swych praw, ponieważ albo mąż powinien ją tego nauczyć albo pozwolić, aby zdobyła tę wiedzę gdzie indziej..."18. Kobiety mogą być uczone przez mężczyzn, jak również mogą być nauczycielkami mężczyzn, bowiem: „Obowiązkiem każdego muzułmanina (mężczyzny lub kobiety) jest poszukiwanie wiedzy"19.

\section{Zasady hidżabu}

Człowiek jest istotą duchowo-cielesną, dlatego islam dba o niego całościowo, podając do wypełniania zasady religijne, które posiadają także wymiar materialny. Do tych zasad należy również sposób ubierania

\footnotetext{
17 Wśród polskich muzułmanek dominuje zwyczaj przyjmowania nazwiska męża, albo używanie dwóch nazwisk: rodowego i męża.

18 Por. Ideals and role models for women in Qur'an, Hadith and Sirah [online], [dostępne 3.01.2013] w World Wide Web http://islamic.org.uk/womright2.html.

19 Tamże.
} 
się muzułmanów, tym samym religia wyznacza trendy w modzie. O ile strój mężczyzny nie budzi kontrowersji w światowej opinii publicznej, o tyle moda obowiązująca muzułmanki jest często komentowana. Charakterystyczny, damski ubiór zgodny z zasadami islamu, wzbudza wiele emocji w świecie o korzeniach łacińskich, upatrując w nim symbolu zniewolenia kobiety, dążącym do jej uprzedmiotowienia.

Strój w kulturze muzułmańskiej ma za zadanie odzwierciedlać i podkreślać różnice między kobietami i mężczyznami oraz charakteryzować płeć. Dlatego istnieje zakaz upodabniania strojów męskich do kobiecych i odwrotnie. Mahomet rozróżnienie to podkreślił słowami: „Nie jest $z$ nas ta, która upodabnia się do mężczyzny, ani ten, który upodabnia się do kobiety"20. Aczkolwiek istnieją pewne wspólne dla obu płci części garderoby, do których należą chociażby szarawary, będące rodzajem spodni. Zasady muzułmańskiego ubioru, zostały określone w prawie, bowiem moda świata islamu jest syntezą szariatu oraz regionalnych zwyczajów. Podstawową zasadą jest zalecenie dotyczące wierzchniego ubrania kobiety, które nie może uwypuklać kształtów jej ciała, dlatego muzułmanki najczęściej noszą luźne sukienki lub długie płaszcze. Nakaz dotyczący stroju kobiety jest zapisany w Koranie: „Powiedz wierzącym kobietom, żeby spuszczały skromnie swoje spojrzenia i strzegły swojej czystości; i żeby pokazywały jedynie te ozdoby, które są widoczne na zewnątrz i żeby narzucały zasłony na piersi...” (24,31). Powyższe słowa stały się podstawowym zaleceniem dotyczącym ubioru, na trwałe wpisując się w tradycję muzułmańską. Owa zasłona nazwana hidżabem, stała się synonimem zniewolenia kobiety muzułmańskiej. Nieustająca dyskusja na temat pozytywnych i negatywnych znaczeń dotyczących chusty w islamie, trwa od wieków. Jedni widzą w niej zniewolenie oraz trwające nadal uprzedmiotowienie kobiety, będące ciągle jeszcze przejawem konserwatyzmu religijnego. Podczas gdy inni widzą w hidżabie znak szacunku i ochrony.

Islam, jak chyba żadna inna tradycja religijna, wprowadził restrykcyjne zasady dotyczące sposobu ubierania się wyznawców,

${ }^{20}$ H. Abu-Rub, B. Zabża, Status kobiety..., dz. cyt., s. 163. 
obowiązujące kobiety oraz mężczyzn. Poglądy te biorą swój początek od arabskiego słowa haja, oznaczającego skromność, wstyd, a także szacunek. Ponadto haja w islamie jest również wyznacznikiem właściwego zachowywania się i postępowania według zasad Allaha. Zgodnie z tradycją muzułmańską Mahomet miał zachęcać do zachowywania haja swoich współwyznawców, mówiąc: „...haja jest częścią wiary”. Ogół zasad obowiązujących w stylu ubierania się, określane jest terminem hidżab, który w języku arabskim oznacza kurtynę, zasłonę. Jednak obecnie znacznie częściej określenie to używane jest w odniesieniu do tradycyjnej chustki noszonej przez muzułmańskie kobiety na głowie, której zadaniem jest szczelne zakrycie włosów. Dzieje się tak, bowiem istnieje przekonanie, że włosy stanowią połowę piękna kobiety, dlatego też muszą być zakryte przed postronnymi mężczyznami. Podziwianie damskich włosów zarezerwowane jest dla męża oraz spokrewnionych z nią mężczyzn ${ }^{21}$.

Kwestia stosowania zwyczajowego ubioru przez muzułmańskie kobiety, jest także poddawana dyskusji w świecie zdominowanym przez islam. Obowiązują odmienne poglądy na jego obecność we współczesnym świecie, są kobiety, które nie doszukują się w tym określonym od wieków i obecnym w ich życiu stylu ubierania się niczego złego. Wręcz przeciwnie, można usłyszeć następującą obronę dotyczącą hidżabu: „Jestem szanowaną kobietą. Nie jestem do oglądania, dotykania, czy rozmawiania dla każdego mężczyzny. Jestem chroniona jak drogocenna perła, która dotykana przez wszystkich staje się czarna i brudna." ${ }^{22}$ Przeciwnicy zaś uważają, że owszem muzułmański styl ubierania spełnia pewne funkcje ochronne ${ }^{23}$, jednakże jest w równym

\footnotetext{
21 Por. Kobiece włosy a religia [online], [dostępne 20.07.2010] w World Wide Web http://www.banzaj.pl/Kobiece-wlosy-a-religia-2383.html.

22 Por. Ideals and role models for women in Qur'an, Hadith and Sirah [online], [dostępne 3.01.2013] w World Wide Web http://islamic.org.uk/womright2.html

${ }^{23}$ Prawdą jest, że w krajach muzułmańskich notuje się znacznie mniej przestępstw na tle seksualnym wobec kobiet, niż w innych krajach. Jednakże trudno jest jednoznacznie stwierdzić w jakim stopniu strój ma na to istotny wpływ. Należy bowiem pamiętać, że prawo muzułmańskie surowo karze wszystkich, którzy dopuszczają się
} 
stopniu dowodem na słabszą płeć mężczyzn, którzy nie potrafią się opanować na widok pięknej kobiety ${ }^{24}$.

Niewątpliwie kwestia ubioru w tradycji islamu jest ściśle powiązana z zasadami moralności muzułmańskiej, zgodnie z którymi pragnie żyć, każdy wierzący w Allaha. Również w Koranie odnaleźć można zalecenia dotyczące sposobu ubierania się: „Powiedz wierzącym: niech spuszczają skromnie spojrzenia i niech zachowują czystość. To dla nich będzie przyzwoitsze (...) Powiedz wierzącym kobietom, żeby spuszczały skromnie swoje spojrzenia i strzegły swojej czystości; i żeby pokazywały jedynie te ozdoby, które są widoczne na zewnątrz; i żeby narzucały zasłony na piersi, i pokazywały swoje ozdoby jedynie swoim mężom lub ojcom...” (24,30-31). Natomiast dalej w Koranie czytamy: „O proroku! Powiedz swoim żonom i swoim córkom, i kobietom wierzących, aby się szczelnie zakrywały swoimi okryciami. To jest najodpowiedniejszy sposób, aby były poznawane, a nie były obrażane." $(33,59)$. Należy jednocześnie zauważyć i wyraźnie podkreślić, że żaden z powyższych tekstów nie nakazuje zakrywania twarzy. Powszechny obecnie wśród ortodoksyjnych muzułmanek obowiązek zakrywania twarzy przed niespokrewnionymi mężczyznami, prawdopodobnie wywodzi się z czasów przedmuzułmańskich. W starożytnej Persji oraz Asyrii i Babilonii znany był zwyczaj zakrywania twarzy przez wolne kobiety, natomiast niewolnice nie posiadały takiego prawa.

Obyczaj zakrywania twarzy przez muzułmanki został wprowadzony przez kalifów dynastii Abbasydów w VIII wieku. Jednakże stosowały go tylko kobiety z wyższych warstw społecznych. Kobiety z niższych warstw pracujące na roli, nie przestrzegały tego zwyczaju, ponieważ strój przeszkadzałby w pracy fizycznej. Taka sytuacja

przestępstw na tle seksualnym. Najlżejszą karą jest publiczna chłosta, zaś w skrajnych wypadkach przestępstwo przeciwko moralności karane jest śmiercią.

${ }^{24}$ Więcej: Q. Amin, The Liberation of Women and the New Woman, b.m.w. 2000. Por. Islam: Kobieta/mężczyzna, w: M. Klocker, M., U. Tworuschka, Etyka wielkich religii, Warszawa 2002, s. 43-44. 
przetrwała do dziś wśród nomadów i Beduinów ${ }^{25}$. Wyjaśnieniem zwyczajowego zakrywania twarzy przez mieszkanki pustyni, może być także przekonanie kobiet, że jasna, a wręcz blada skóra jest oznaką szlachetności ${ }^{26}$.

Obecnie kobiety muzułmańskie stosują dwa rodzaje zasłon na twarz. W zależności od obowiązujących zwyczajów na danym terenie, są to: kwef oraz nikab. Kwef jest popularnym określeniem zasłony na twarz, noszonej przez muzułmanki ${ }^{27}$. Natomiast nikab ${ }^{28} \mathrm{w}$ tradycji muzułmańskiej jest rodzajem nakrycia głowy, połączony z zasłoną na twarz. Uzasadnieniem noszenia zasłony była ochrona kobiet przed niemoralnym i nieodpowiednim zachowaniem mężczyzn, wynikającym z zachowań seksualnych i naturalnej pożądliwości mężczyzny. Zasłona miała na celu ukryć atrakcyjność fizyczną i seksualną kobiety. Potwierdzeniem takiego zastosowania owej zasłony są słowa Koranu: „A kobiety starsze, które się już nie spodziewaja matżeństwa, nie będa miały grzechu, jeśli zdejma swoje szaty, jednakże w taki sposób, aby nie ukazywać swoich ozdób" $(24,60)$. Fragment ten jest wymownym potwierdzeniem szczególnej ochrony godności i czci młodej kobiety. Wyraźnie podkreślone w nim zostało, że kobiety dojrzałe, często wdowy nie mają obowiązku rygorystycznego przestrzegania tego zalecenia. W tym miejscu warto podkreślić, wybitną pozycję kobiety - matki, często również nestorki w rodzinie muzułmańskiej,

\footnotetext{
25 Por. A. Nalborczyk, Czy istnieje strój kobiety muzułmańskiej?, w: Szata oddaje ludzkie obyczaje, czyli o strojach ludów Azji i Afryki, J. Jurewicz, J. Rogala (red.), Warszawa 2008, s. 64.

${ }^{26}$ Dążenie do posiadania jasnej skóry było i nadal jest powszechne w Indiach. Od najdawniejszych czasów kobiety, zwłaszcza z wyższych sfer, stosowały różnego rodzaju maści, wybielające skórę, aby tym samym nie być podobne do robotnic pracujących w polu. Analogiczną sytuację można było zaobserwować w szlacheckiej Polsce, kiedy to panie z wysoko urodzone w pogodne dni wychodziły na spacer w kapeluszach i pod parasolką, osłaniając twarz przed słońcem.

27 Por. W. Kopaliński, Słownik mitów i tradycji kultury, t. II, Warszawa 2007, s. 141.

28 Istnieją dwie formy nikabu: połowiczny i całkowity. Nikab połowiczny, błędnie nazywany hidżabem, składa się z chusty okrywającej głowę oraz włosy, pozostawiając jednak twarz, oczy i czoło niezasłonięte. Natomiast nikab całkowity dokładnie zakrywa głowę i twarz. Widzenie otoczenia umożliwia jedynie wąski otwór na oczy.
} 
której należy się szacunek ze względu na wiek i doświadczenie życiowe. Zazwyczaj najstarsza kobieta rządzi domem, ciesząc się przy tym szczególnym autorytetem własnej rodziny, jak również dalszego otoczenia.

Zgodnie z nauką islamu, ubranie zostało dane człowiekowi przez samego Boga, bowiem wskazują na to słowa Koranu: „O synowie Adama! My zesłaliśmy wam ubranie, aby zakrywało wasza nagość..." $(7,26)$. Zatem może ono stanowić o statusie materialnym człowieka, ale pobożny wierzący nie powinien, w żadnej sytuacji obnosić się swoim majątkiem, dlatego również w odniesieniu do ubioru należy stosować umiar, zgodnie ze słowami Mahometa: „Ktokolwiek założy ubiór dla sławy w tym życiu, temu Allah założy ubiór poniżenia $w$ dniu sadu ostatecznego..."29. Powyższe słowa stają się zatem podstawą interpretowania obowiązku skromnego ubioru, jako gwarancji równego traktowania wszystkich ludzi, a w sposób szczególny kobiet - zamożnych i biednych, młodych i starszych, szczupłych i tęższych. Owym uniwersalnym strojem jest niewątpliwie abaja ${ }^{30}$, która dzięki luźnemu krojowi ukrywa naturalne kształty kobiet. W ten sposób nauka islamu stara się zapobiegać niewłaściwym nastrojom w społeczeństwie, zwłaszcza w małych społecznościach muzułmanów, dbając o to, aby relacje międzyludzkie nie były niszczone przez niezdrowe korzystanie z majątku. Bowiem w naturze ludzkiej leży, naturalne dążenie do rywalizowania między sobą oraz udowadniania osobistej, wyższej pozycji. Ponadto istotnym elementem jest także polecenie, które wydał sam Mahomet. Dotyczyło ono konieczności zachowania odrębności w postępowaniu oraz wyglądzie zewnętrznym przez wyznawców Allaha i nieupodabnianiu się do niewiernych. Jednocześnie prorok przestrzegał swoich współbraci w wierze, następującymi słowami: „W późniejszym czasie w moim społeczeństwie będą kobiety

\footnotetext{
29 H. Abu-Rub, B. Zabża, Status kobiety...., dz. cyt., s. 161-162.

30 Abaja w zależności od regionu przyjmuje odmienne określenia. W Egipcie jest to milaja, w Iraku abaja, w Arabii Saudyjskiej dżilbab, w Turcji czarczaf, w Afganistanie burka, w Iranie czador. Por. A. Nalborczyk, Czy istnieje strój kobiety muzułmańskiej..., dz. cyt..., s. 65.
} 
ubrane, a jednocześnie nieubrane, ich głowy będą stojące jak garby wielbłądów. Przeklinajcie je, gdyż są one przeklęte"31.

Przestrzeganie zasad hidżabu, zwłaszcza w XXI wieku, nie oznacza jednak konieczności noszenia brzydkiego ubrania, przypominającego worek ${ }^{32}$. Do zmiany postrzegania muzułmańskiej mody, przypadkiem przyczynił się europejski polityk. Bowiem negatywna wypowiedź prezydenta Francji Nicolasa Sarkozy'ego na temat muzułmańskich strojów kobiecych, który powiedział: „Burka to nie symbol religijny, a znak podporzadkowania i poniżenia. Nie jest mile widziana na terytorium Republiki Francuskiej" ${ }^{\text {33 }}$ spowodowała reakcję kreatorów mody. John Galliano ${ }^{34}$ i Carolina Herrera oraz wielu innych uznanych projektantów zorganizowało w 2009 roku w Paryżu pokaz mody, w wersji haute couture ${ }^{35}$ zgodnej z zasadami islamu ${ }^{36}$. Pomysłodawczyni wydarzenia - Libanka Daria Tarhini ${ }^{37}$, chciała aby podczas gali mody zaproponować muzułmańskim kobietom nowoczesne abaje. Szczególnie Saudyjki są zobowiązane przez prawo szariatu do okrywania ciała luźnymi płaszczami. Często pod abają kobiety noszą markową odzież uznanych kreatorów mody, którą ze względów obyczajowych należy zakryć. Dlatego powstał pomysł zaprojektowania abai przez artystów pracujących dla takich domów mody jak Christian Dior, Nina Ricci, Azzaro oraz Alberta Feretti. Pragnieniem twórców jest zatem aby muzułmanki przestrzegające zasad hidżabu nosiły swój strój z przyjemności, a nie z obowiązku.

\footnotetext{
${ }^{31}$ H. Abu-Rub, B. Zabża, Status kobiety...., dz. cyt., s. 161-162.

32 Na temat mody stosowanej przez muzułmanki w Europie Zachodniej, więcej w: E. Tarlo, Visibly Muslim: Fashion, Politics, Faith, Oxford 2012.

33 Por. Burkini zakazane. Muzułmanki protestuja [online], [dostępne 20.07.2010] w Word Wide Web http://www.iwoman.pl/na-serio/inews/burkini;zakazne;muzu lmanki;protestuja,254,0,529406.html

34 John Galliano (ur. 28.11.1960) projektant domu mody Christian Dior.

35 Haute couture tzw. wysokie krawiectwo, charakteryzuje się ubraniami szytymi na zamówienie, w pojedynczych egzemplarzach.

36 Należy zaznaczyć, że ów pokaz odbył się w hotelu George V, który należy do saudyjskiego księcia Alwalida bin Talala.

37 Daria Tarhini jest szefową ekskluzywnej sieci hotelowej Saks Fifth Avenue w Arabii Saudyjskiej.
} 
Podczas pokazu zaprezentowano abaje różnego rodzaju: patchworkowe, aksamitne, koronkowe oraz bogato zdobione perłami i kryształkami Swarowskiego ${ }^{38}$. Ponadto menadżerowie uznanych domów handlowych, np. Harrods dostrzegają zapotrzebowanie na markowe ubrania, zgodne z tradycją islamu. Nie bez znaczenia jest również fakt, że rynek bliskowschodni jest duży, a ponadto bogaty, co pozostaje nie bez znaczenia w czasie kryzysu ekonomicznego ${ }^{39}$.

Mimo zabiegów kreatorów mody, muzułmanki ciągle szukają własnego, osobistego wyróżnika, który pozwoli nieco odróżniać się od innych podobnie ubranych sióstr w wierze. Coraz częściej takim indywidualnym wyróżnikiem stają się dodatki, a więc buty i torebki. Islam nie precyzuje zasad jakie mają spełniać buty, dlatego kobiety starają się aby ten element stroju był niebanalny oraz wyjątkowy. Często w kontrastującym kolorze do pozostałego stroju, a także unikalnym fasonie ${ }^{40}$. Także typowy atrybut każdej kobiety, niezależnie od wyznawanej religii, a więc torebka coraz częściej staje się wyróżnikiem wiernej Allaha. Zamożne muzułmanki wybierają egzemplarze z kolekcji Prady i Gucciego, ale także polskiej projektantki Bożeny Batyckiej ${ }^{41}$.

Należy również zaznaczyć, że powyższe zasady przestrzegania rygorystycznego i wręcz ascetycznego ubierania, obowiązują w zwykłym, codziennym życiu społecznym. W relacjach intymnych między żoną i mężem przestają one obowiązywać. Kobieta może, a nawet ma obowiązek dbać o swój wygląd w taki sposób, aby czuć się i być atrakcyjna dla swojego męża. Prawdopodobnie z tego powodu, kraje

\footnotetext{
38 Abaje będą dostępne w wersji ready-to-wear w sklepach sieci Saks Fifth Avenue w Rijadzie, Dżuddzie, Bahrajnie i Dubaju. Cena od 1500 do 2000 Euro. Por. I. Bogus, Najsłynniejsi projektanci ubiora muzułmanki, „Dziennik” 2009, nr 150 (971), s. 24. 39 Por. D. Walewska, Rewolucja w świecie mody. Abaja z Harrodsa, „Rzeczpospolita” [online], [dostępne 13.07.2010] w World Wide Web http://www.rp.pl/ artykul/508187_Rewolucja_w_swiecie_mody__abaja_z_Harrodsa.html

40 Por. M. Dziekan, Dzieje kultury arabskiej, Warszawa 2008, s. 435.

41 Por. D. Walewska, Rewolucja w świecie mody. Abaja z Harrodsa, „Rzeczpospolita” [online], [dostępne 13.07.2010] w World Wide Web http://www.rp.pl/ artykul/508187_Rewolucja_w_swiecie_mody__abaja_z_Harrodsa.html
} 
Bliskiego Wschodu są głównymi importerami ekskluzywnej bielizny damskiej z Europy ${ }^{42}$.

Podsumowując damską modę muzułmańską należy stwierdzić, że wbrew powszechnej w Europie koncepcji, zasady hidżabu stosowane z umiarem, są pozytywnie postrzegane przez kobiety je stosujące. Nie ulega wątpliwości, że hidżab stanowi ochronę przez napastliwością na tle seksualnym. Ponadto trzeba pamiętać, że muzułmanki wychowywane są w przekonaniu o właściwości oraz stosowności takiego stroju. Zaś zachowanie skromności wraz z powściągliwością jest właściwe kobiecie, która dba o honor swój i rodziny. Dlatego trudno wymagać od nich zmiany swoich przekonań i żądać przewartościowania światopoglądu. Owszem w historii przemysłu odzieżowego zdarzały się rewolucje, jak np. Coco Chanel, pozostaje tylko pytanie czy same zainteresowane, a więc muzułmanki chcą aby osoby wychowane w innej kulturze, decydowały o tym, co dla niech jest lepsze. Dla muzułmanki ukrywanie się za długą i powłóczystą szatą nie jest karą, ani zniewoleniem.

\section{Prawa kobiety muzułmańskiej}

Wizerunek muzułmanki kształtowany był od wieków przez myśl religijną, jak również wynikające $z$ biologii różnice między płciami, według których kobieta ma do wypełnienia określoną funkcję przypisywaną jej przez społeczność. Niewątpliwie, na postrzeganie wiary przez niewiasty, istotne znaczenie ma ich wychowanie, wyniesione $\mathrm{z}$ domu rodzinnego. Ponadto ważne jest także pochodzenie muzułmanek oraz osobiste przywiązanie do religii i praktykowania jej zasad w życiu codziennym. Dlatego nie można wskazać jednego, spójnego, a nade wszystko właściwego wzorca postępowania muzułmanki. Natomiast nie ulega wątpliwości, że kobiety dokładają wszelkich starań,

\footnotetext{
42 Zjednoczone Emiraty Arabskie i Arabia Saudyjska odbierają 77\% eksportu bielizny z Europy do Zatoki Perskiej. Na 3. miejscu znajduje się Kuwejt z 16\%. Takie dane przedstawił European Fashion and Textile Export Council (EFTEC). Por. Polska firma na targach w Dubaju [online], [dostępne 21.07.2010] w World Wide Web http://www.bielizna.home.pl/index.php?mpa=500\&id=70.
} 
aby ich działania na rzecz rodziny i społeczności, były jak najlepsze oraz zgodne z wymaganiami Koranu.

Islam arabski uczy, że kobieta jest wyczekiwaną i upragnioną żoną dla mężczyzny, dlatego kobieta ma wszelkie prawo odczuwać własną wysoką wartość. Utrzymywanie dystansu wobec obcych mężczyzn, zasłanianie się hidżabem tylko tę wartość potęguje, a zarazem wzrasta poważanie i szacunek dla kobiety ${ }^{43}$. Muzułmanki wyznające islam klasyczny, nieskażony chrześcijańskimi naleciałościami, a więc bardzo jurydyczny i do przesady zgodny z literą Koranu, promują arabski styl życia oraz działalność kobiet. Manifestują swoją przynależność religijną przede wszystkim przez noszenie hidżabu, zgodnie ze słowami Allaha: „Powiedz wierzącym kobietom, żeby spuszczały skromnie swoje spojrzenia i strzegły swojej czystości (...) i żeby narzucały zasłony na piersi..." $(24,31)$. Coraz częściej nowoczesne muzułmanki, żyjące w Europie lub liberalnych pod względem kulturowym, krajach muzułmańskich, jak chociażby Maroko, świadomie zakładaja chustkę, będącą zewnętrznym wyrazem przynależności do islamu, wyraźny akcent poddania się woli Bożej oraz zwyczajom religii. Radykalny islam uważa, że Allah nakazał kobietom okrywanie się, aby w ten sposób podkreślić swoją odmienność od niemuzułmanek oraz niereligijnych muzułmanek.

Status kobiety muzułmańskiej w społeczności oraz przestrzeganie jej praw, wywodzących się z Koranu, uzależniony jest od warunków obyczajowych, obowiązujacych na danym terytorium. Zgodnie z nakazami religijnymi byt kobiety winien być odpowiednio zabezpieczony, bowiem tak nakazuje Święta Księga: „O wy, którzy wierzycie! Nie jest wam dozwolone, abyście dziedziczyli kobiety wbrew ich woli. I nie przeszkadzajcie im zabrać część tego, co im daliście (...) Obchodźcie się z nimi w sposób przyzwoity" $(4,19)$. Ów szacunek zauważył już w XIV wieku podróżujący po Azji arabski obieżyświat Ibn Battuta, pisząc w dzienniku podróży: „najciekawszą na Krymie rzeczą jest to, że kobiety Tatarów są bardzo szanowane, a nawet osławiane

43 Por. S. Nasr, Idee i wartości..., dz. cyt.,s. 110 - 111. 
wyżej od mężczyzn" ${ }^{44}$. Takie postrzeganie kobiety w Polsce, obowiązuje do dziś. Polka-Tatarka to przede wszystkim kobieta posiadająca wolność w postępowaniu i działaniu. Aczkolwiek do począrku XX wieku, kobiety nie mogły brać udziału w zgromadzeniu ogólnym gminy wyznaniowej, co przekładało się na brak prawa głosu przy wyborze imama lub muezina. Jednak kobiety zawsze brały czynny udział w pracy oraz działalności gmin, a także instytucji propagujących kulturę tatarską, zajmując w nich także kierownicze stanowiska ${ }^{45}$.

Muzułmanka została obdarzona całym wachlarzem praw, wynikających z zasad religijnych. Niemniej jednak, mimo znaczącej pozycji w społeczeństwie, jej swoboda w korzystaniu z należnego prawa oraz wolność w podejmowaniu decyzji bywa ograniczana. Mimo gwarancji prawnych, wywiedzionych z Koranu, najwięcej ograniczeń dotyczy rozwodu na wniosek kobiety ${ }^{46}$.

Rozwód, a więc rozwiązanie ważnie zawartego związku małżeńskiego za życia małżonków, zawsze jest postrzegany jako krzywda wyrządzona rodzinie. Ponadto $w$ tradycji islamu, jest on także rozumiany jako zerwanie jedności społeczności wierzących. W Arabii przedmuzułmańskiej mężczyzna miał nieograniczone prawo dokonywania rozwodów; mógł odchodzić i powracać do żony wielokrotnie. Doktryna islamu sprzeciwiła się takim praktykom, uznając, że małżeństwo jest więzią między dwojgiem ludzi, która nie powinna być zerwana, chyba że zaistnieją bardzo ważne powody. Dlatego bywa nazywany „nagannym zezwoleniem”47, zaś sam Mahomet mówił o nim: „Dla Boga najwstrętniejszą z rzeczy dozwolonych jest rozwód"48. At-talak, czyli rozwód jest zatem ostatecznym środkiem,

\footnotetext{
44 Cyt za: T. Milczarek, Polska Tatarka w świecie i w domu, „Życie Tatarskie” 2001 nr 7, s. 8.

45 Tamże, s. 9.

46 Klasyczna nauka dotycząca prawa muzułmańskiego wielokrotnie podkreśla, że prawo do rozwodu na wniosek kobiety, stanowi jedno z podstawowych praw danych przez islam kobiecie.

47 Por. H. Abu-Rub, B. Zabża, Status kobiety ..., dz. cyt., s. 118.

48 E. Machut-Mendecka, Świetlista twarz muzułmanki, „Znak” 1998, nr 1 (512), s. 36 .
} 
którego celem winno być uleczenie prawnych problemów zaistniałych między małżonkami.

Prawo muzułmańskie dopuszcza rozwód na wniosek kobiety, nazywając go al-chol'a, co tłumaczone jest jako zdejmowanie, bowiem w islamie kobieta i mężczyzna porównywani są do ubrań: „one są ubiorem dla was, a wy jesteście ubiorem dla nich” $(2,187)$, a w wyniku rozwodu kobieta niejako porzuca ten strój. Podstawą do wystąpienia o rozwód przez żonę jest nie wywiązywanie się męża z obowiązków zawartych w kontrakcie przedślubnym. Małżeństwo jako przede wszystkim kontrakt cywilny ${ }^{49}$, zawiera ustalenia dotyczące małżonków, stanowiące podstawę wzajemnych zobowiązań kobiety i mężczyzny. Jeśli mężczyzna nie realizuje owych ustaleń, kobieta może wystąpić o rozwód. Ponadto kobieta ma prawo podjęcia decyzji o rozwiązaniu małżeństwa wówczas, gdy mężczyzna cierpi na chorobę zagrażająca jej zdrowiu (weneryczną lub zakaźną), a zataił ten stan przed ślubem. Powodem wystąpienia o rozwód może być także nieuczciwe prowadzenie interesów handlowych lub usługowych. Powodami rozwiązania małżeństwa przez al-chol’a są także inne przesłanki, wśród których należy wymienić niewystarczającą religijność mężczyzny oraz starość lub słabość, w wyniku czego kobieta nie może dopełniać obowiązków małżeństwa ${ }^{50}$. Zawsze nadrzędnym powodem starania się o rozwód przez kobietę jest okrutne traktowanie żony przez męża ${ }^{51}$. Do al-chol'a dochodzi także wówczas, gdy żona nienawidzi swojego męża i nie jest w stanie spełniać obowiązków

\footnotetext{
49 Dokument akd az-zawadż podpisywany jest przed urzędnikiem, a zawarte w nim są ustalenia dotyczące: mahru, dotyczące wielożeństwa mężczyzny, bowiem pierwsza żona może zastrzec w kontrakcie ślubnym, że chce pozostać w związku monogamicznym. Ponadto gama ustaleń ślubnych może być różnorodna. Zapisane w dokumencie są szczegółowe ustalenia miedzy rodzinami, do których najczęściej należą: pozwolenie mężczyzny do kształcenia żony, wyrażenie zgody na jej pracę (lekarz, nauczycielka), itp.

50 Por. M., U., Tworuschka, Islam, Warszawa 2005, s. 155.

51 Por. E. Szymański, Zwyczaje, obrzędy i symbole religijne w islamie, w: J. Keller, W. Kotański (red.), Zwyczaje, obrzędy i symbole religijne, Warszawa 1974, s. 500.
} 
małżeńskich wobec niego ${ }^{52}$. Współcześnie w krajach arabskich obowiązuje prawo gwarantujące kobiecie wystąpienie o rozwód z powodu niezgodności charakterów. Warunkiem rozwiązania małżeństwa na takiej podstawie, jest zwrócenie mężowi daru przedślubnego (mahru) i zrzeczenie się przez żonę prawa do należnych alimentów ${ }^{53}$. Niemniej jednak rozwód uważany jest jako zło i ostateczność. Z tego względu małżeństwo stara się doprowadzić do porozumienia, aby uchronić swoją rodzinę, a przede wszystkim dzieci przed rozbiciem jedności.

\section{Feminizm w świecie arabsko-muzułmańskim}

Prawo społeczne wynikające z Koranu, gwarantujące kobietom określony status nie podlega dyskusji. Koran, jak każdy tekst święty nie podlega ingerencji człowieka, co do jego treści. Natomiast zupełnie odrębną kwestią jest interpretacja tego tekstu oraz stosowanie praw z niego wynikających, zwłąszcza gdy dotyczą kobiet. Dotychczas w niniejszym artykule ukazano regulacje dotyczące statusu kobiety w islamie. Pojawia się jednak pytanie: $w$ jakim stopniu owe gwarantowene, wręcz fundamentalne prawa przyznane przez religię kobietom ponad czternaście wieków temu, są respektowane i stosowane obecnie?

Badania socjologów wykazują, że część Arabek ma świadomość własnego, podrzędnego, niższego statusu względem mężczyzn, tak w rodzinie, jak i w społeczeństwie. Świadomość ta sprawia, że kobiety dążą do zmiany tego stanu. Kobiety zmagają się z nierównym traktowaniem, ze względu na dominację ustrojów patriarchalnych, w wielu częściach świata, zarówno chrześcijańskiego jak i muzułmańskiego. Różnica jednak polega na tym, że kobiety kręgu kultury łacińskiej, nie musiały zmagać się dodatkowo z kwestią religijną, podczas gdy dla muzułmanek religia jest problemem kluczowym. W tym miejscu pojawia się drugie istotne pytanie: czy w tak ortodoksyjnej religii jaką jest islam, pozostaje miejsce na feminizm? Odpowiedź jest prosta - tak, bowiem w każdym ustroju, w którym pojawia się ucisk lub jakakolwiek inna forma dyskryminacji, powstaje ruch oporu

52 Tamże, s. 126.

53 Por. M. Zyzik, Małżeństwo..., dz. cyt., s. 163. 
i wyraźnego sprzeciwu wobec krzywdzącej określoną grupę, w tym przypadku kobiet, sytuacji.

Feminizm jest swego rodzaju stanem świadomości oraz aktywności kobiet, dążących do przezwyciężenia ich marginalizacji i dyskryminacji w życiu społecznym. Dążenia te są wsparte na przekonaniu o konieczności, a przede wszystkim możliwości zmiany dotychczasowego podziału ról ze względu na płeć, obowiązującym w danym społeczeństwie. $^{54}$

Podejmując jednak kwestię feminizmu w świecie arabsko-muzułmańskim, należy pamiętać o trudnościach związanych z terminologią. Określenie feminizm jest ściśle powiązane ze światem euroamerykańskim, bardzo często postrzeganym w obszarze kręgu arabsko-muzułmańskiego, jako wrogi, zepsuty moralnie, nierzadko utożsamiany z czasem kolonizacji i siłowego narzucania obcych kulturowo oraz religijnie zwyczajów. Ponadto należy także podkreślić, że arabskie działaczki na rzecz równouprawnienia kobiet, nie nazywają siebie feministkami. Zapewne $\mathrm{z}$ tego powodu częściej stosowany jest przymiotnik feministyczny lub gender activism, służące określeniu aktywności dążących do przeciwdziałania dyskryminacji kobiet. ${ }^{55}$ $\mathrm{W}$ tradycji muzułmańskiej, feminizm podobnie jak w świecie euroamerykańskim, posiada rozmaite oblicza, wśród których wyróżniaja się trzy główne prądy. Ateistyczny postrzegający religię jako przyczynę i powód ucisku kobiety, sekularystyczny stojący wobec religii obojętnie oraz religijny. W feminizmie religijnym można wyróżnić dwa rodzaje: muzułmański i islamski.

Feminizm muzułmański jest ruchem o dłuższej historii. Powstał u schyłku XIX wieku w krajach muzułmańskich. Ten rodzaj feminizmu, co prawda akceptował religię jako element ludzkiej egzystencji, ale pozostawał i nadal pozostaje ideologią świecką, czerpiącą idei politycznych. Początki feminizmu muzułmańskiego utożsamiane

\footnotetext{
54 Por. E. Malinowska, Feminizm europejski, demokracja parytetowa a polski ruch kobiet, Łódź 2002, s. 20.

55 Por. J. Brzezińska, Islam i feminizm? Ruch kobiet w Egipcie na rzecz róznouprawnienia płci, „Acta Universitatis Lodziensis. Folia Sociologica” 2011, nr 39, s. 130.
} 
są z Egiptem, bowiem kraj ten uważany jest za kolebkę emancypacji muzułmanek. Działalność organizacji skoncentrowana była na pracy u podstaw, a więc przede wszystkim na poprawie zwykłej, codziennej sytuacji kobiet. Działaczkom zależało na dostępie kobiet do edukacji, ochrony zdrowia, przyznania praw wyborczych, a co się z tym wiąże, także dostępu do funkcjonowania w sferze publicznej, aż po możliwosć wykonywania zawodów, do niedawna zarezerwowanych tylko dla mężczyzn. ${ }^{56}$ Co ciekawe takie postawy ruchów feministycznych, często były i nadal są krytykowane przez umiarkowanych muzułmańskich badaczy, ze względu na dostrzeganie swego rodzaju zagrożeń czyhających na muzułmankę. Analogicznie do sytuacji kobiet w Europie, które w wyniki szeroko rozumianej emancypacji, zmuszone zostały do pracy etatowej, przy jednoczesnym pozostawaniu żoną i matką.

Natomiast feminizm islamski powstał na przełomie lat 80. i 90. XX wieku, który zapoczątkowały muzułmańskie intelektualistki, pracujące na uniwersytetach. W tej grupie, kręgu języka arabskiego, wykształciło się również określenie niswiyya, opisujące zjawisko feminizmu, bowiem oznacza zarówno feministyczny, jak i kobiecy. Feminizm w tradycji islamu rozumiany jest jako nałożenie różnego rodzaju ograniczeń na kobiety, ze względu na ich płeć. ${ }^{57}$ Nie bez znaczenia pozostał międzynarodowy charakter owej aktywności kobiecej. Wskazał on bowiem na dwa istotne elementy, u podstaw których znajduje się religia, a więc identyfikacja i poczucie wspólnoty. Istotną cechą feminizmu islamskiego jest podkreślanie, że głoszone postulaty dotyczące równości płci, wywodzone są z religijnych zasad islamu. Głównym założeniem feministek islamskich jest zwrócenie uwagi, że nierówność, dyskryminacja, przemoc których to doświadczają

\footnotetext{
56 Por. M. Bobako, Feminizm islamski. Niechciane dziecko islamu politycznego [online], [dostępne 28.07.2015] w World Wide Web http://www.praktykateoretyczna. pl/czasopismo/feminizm-islamski-niechciane-dziecko-islamu-politycznego/.

57 Por. J. Brzezińska, Islam i feminizm..., art. cyt., s. 132.
} 
muzułmanki są zaprzeczeniem przesłania Koranu. Dlatego celem ugrupowań feministycznych jest reinterpretacja religii. ${ }^{58}$

Rozwijający się ruch kobiet muzułmańskich na Bliskim Wschodzie oraz w Afryce Północnej, kieruje swoje postulaty ku Koranowi. Podstawą owych dążeń równościowych jest zwrócenie uwagi męskiej części społeczności muzułmańskiej, na nauczanie Świętej Księgi oraz Tradycji Mahometa - Sunny, a w konsekwencji również szarii. Dopiero na tak przygotowanych fundamentach religijnych, podnoszone są argumenty z dziedziny praw człowieka i demokracji. ${ }^{59}$

Aktywistki muzułmańskie, jako podstawę swojej działalności głoszą przekonanie, że islam jest religią równości wszystkich ludzi, tak mężczyzn jak i kobiet, o czym poucza Koran: „Ktokolwiek pełni dobre dzieła - mężczyzna czy kobieta - i jest wierzącym, tacy wejdą do Ogrodu i nie doznają niesprawiedliwości” $(4,124)$. We fragmencie tym podkreślona została także kwestia sprawiedliwości wobec kobiet, z tego względu nauka islamu potępia wszelkie uciskanie kobiet. W Świętej Księdze znajduje się znacznie więcej argumentów, wskazujących na równość kobiet i mężczyzn. Jednakże problem gorszej sytuacji kobiety w tradycji islamu, ukształtowany w ciągu wieków, posiada inne podłoże. Mianowicie jest wynikiem kształtowania się prawa muzułmańskiego - szarii, głównie w IX wieku, formowanego pod silnym wpływem ówczesnych praktyk oraz tradycji patriarchalnych. Z tego powodu aktualna sytuacja kobiet muzułmańskich, jest wynikiem niewłaściwej interpretacji Słowa Bożego i Tradycji

\footnotetext{
58 Por. M. Bobako, Feminizm islamski. Niechciane dziecko islamu politycznego [online], [dostępne 28.07.2015] w World Wide Web http://www.praktykateoretyczna. $\mathrm{pl} /$ czasopismo/feminizm-islamski-niechciane-dziecko-islamu-politycznego/.

59 Demokracja w świecie arabsko-muzułmańskim, podobnie jak feminizm euroamerykański, powoduje problemy terminologiczne. Przede wszystkim dlatego, że język arabski nie posiada własnego słowa demokracja, stosowane jest dimukratijja. Świat tradycji Koranu, inaczej postrzega demokrację, anieżeli Europa. Myśliciele arabscy, uważają, że wybierając między demokracją a dyktaturą - wybrać należy demokrację, ale przy wyborze między demokracją a islamem - wybór jest jeden islam. Por. A. Wąs, Islam a demokracja [online], [dostępne 28.07.2015] w World Wide Web http://religie.wiara.pl/doc/472198.Islam-a-demokracja.
} 
Mahometa, a nawet nadużywania religii przez mężczyzn, w celu utrzymania patriarchatu. Niewątpliwie takie postrzeganie przyczyn sytuacji kobiet w świecie muzułmańskim, stanowi istotny argument, do podejmowania działań mających na celu zmianę ich statusu. Feminizm islamski dąży do tego, aby kobiety stały się aktywnymi uczestniczkami życia, a nie tylko pozostawały przedmiotem badań oraz dyskusji. Feminizm islamski jest ideologią konserwatywną, co uwidacznia się chociażby w braku podważania konieczności noszenia hidżabu. Zaś godność kobiety uwypukla się w jej podporządkowaniu wszystkim nakazom prawa. Jednocześnie zwolenniczki feminizmu islamskiego domagają się równego udziału w modlitwach publicznych oraz rozmaitych ceremoniach religijnych, a także dostępu do edukacji religijnej dziewcząt. ${ }^{60}$

Kobietami zasłużonymi na rzecz zmiany statusu muzułmanek w społeczeństwie patriarchalnym są: Fatima Mernissi oraz Amina Wadud. Marokanka Fatima Mernissi absolwentka uniwersytwtów w Rabacie i Stanach Zjednocznonych, jest obecnie profesorem socjologii, pracuje w Rabacie. Zajmuje się relacjami mężczyzny i kobiety w społeczeństwie przed nastaniem islamu oraz w czasach muzułmańskich. W namyśle naukowym oraz działalności społecznej, podejmuje zagadnienia dotyczące współczesnych kobiet muzułmańskich, ze szczególnym uwzględnieniem konsekwencji przemian ekonomicznych, cywilizacyjnych i ustrojowych. Fatima Mernissi podkreśla jednocześnie znaczenie przesłania koranicznego, któremu należny jest szacunek, bowiem jest gwarantem tożsamości religijnej i kulturowej. Jej działalność na rzecz kobiet, zwłaszcza starszych i rozwiedzionych jest istotna, dzięki czemu określana jest mianem rzeczniczki muzułmanek, a ponadto pełni funkcję doradcy do spraw kobiet w islamie w UNESCO. ${ }^{61}$

\footnotetext{
${ }^{60}$ Por. A. Nalborczyk, Współczesna sytuacja kobiet muzułmańskich, w: Nie bój się islamu. Leksykon dla dziennikarzy, red. A. Marek, A. Nalborczyk, Warszawa 2005, s. 71-72.

${ }^{61}$ Por. M., U. Tworuschka, Religie świata - Islam, Warszawa 2009, s. 70-71.
} 
Natomiast Amina Wadud, jest amerykańską konwertytką na islam. Jej ojciec był pastorem baptystycznym. Naukowo zajmuje się egzegezą Koranu. Dlatego też jej postulaty dotyczą odczytania tekstu świętego. Uważa bowiem, że na należy na nowo dokonać interpretacji Koranu, aby wskazać zawarte w nim teksty dotyczące kobiet i mężczyzn. W jej opinii, konieczne jest wyjaśnienie tych wersetów, które odnosiły się do konkretnej sytuacji społecznej czasów Proroka, a więc wieku VII. Ze względu na zmiany w świecie, muszą one ulec reiterpretacji w nowym kontekście historycznym.

Nieco inaczej rozwija się feminizm wśród muzułmanek żyjących w Europie. Zazwyczaj interpretują one źródła religijne w kontekście europejskim, zgodnie z aktualną sytuacją, w której żyją. Wśród głównych postulatów europejskich muzułmanek znajduje się przekonanie, że obecnie mężczyźni nie powinni decydować o losie kobiet, bowiem przestali być jedynymi żywicielami rodzin. Europejskie muzułmanki pracują, często są niezależnymi kobietami, zajmującymi istotone funkcje w społeczeństwie, to też mężczyzna nie możne sprawować nad kobietą władzy. ${ }^{62}$

Zmiany zachodzące $\mathrm{w}$ postrzeganiu kobiet w społeczeństwie muzułmańskim są coraz bardziej widoczne i nie pozostają jedynie tematem dyskusji. Obecnie kobiety zajmują najwyższe stanowiska ${ }^{63}$ w państwach muzułmańskich, zasiadają w parlamentach oraz podejmują zawody, do niedawna zarezerwowane tylko dla mężczyzn. Muzułmanki zyskały także możliwość uprawiania dyscyplin sportowych, postrzeganych jako typowo męskie, jak chociażby piłka nożna. Aczkolwiek w Iranie, na mecze ligi kobiecej nie mogą przychodzić mężczyźni. Kobiety kręgu kultury arabsko-muzułmańskiej reprezentują także swoje kraje podczas zawodów międzynarodowych oraz olimpiadach.

\footnotetext{
${ }^{62}$ Por. A. Nalborczyk, Współczesna sytuacja..., dz. cyt., s. 74.

63 Kobieta prezydent w Indonezji Megawati Sukarnoputri (2001-2004), kobiety na stanowiskach premierów: w Pakistanie Benazir Bhutto (1988-1990; 1993-1996), w Turcji Tansu Ciller (1993-1996), w Bangladeszu Chaleda Zia (1991-1996; 2001-2006). We Francji minister sprawiedliwości Rashida Dati (2007-2009).
} 
Mimo ożywionych ruchów feministycznych na Bliskim Wschodzie, ciągle jeszcze Saudyjki nie posiadają prawa po prowadzenia samochodów. Zakaz ten argumentowany jest dbaniem o zdrowie kobiety. ${ }^{64}$

\section{Dżihad kobiet}

Dżihad w powszechnej opinii błędnie utożsamiany jest z walką zbrojną oraz sposobem prowadzenia wojny ${ }^{65}$. Słowa dżihad, $w$ języku arabskim nie oznacza agresji, a zatem nie oznacza też prowadzenia wojny w sensie zbrojnym oraz nie oznacza zabijania ludzi. Terminem określającym cechy wojny będącej działaniem agresyjnym jest słowo kital, oznaczające „prowadzić wojnę”, „zabijać”, „bitwa”. ${ }^{66}$ Zatem dżihad oznacza dosłownie „dokładanie starań w jakiejś dziedzinie”"67. Oznacza także usilne dążenie do czegoś, nierzadko w odniesieniu do wysiłku intelektualnego oraz społecznego. $Z$ tego powodu postępowe stronnictwa muzułmańskie, promują pozytywny dżihad, rozumiany jako podejmowanie wysiłku na drodze Boga, ale ów wysiłek ma służyć dobru osoby oraz społeczeństwa. W tak scharakteryzowanym dżihadzie może brać udział każdy wierzący, również kobiety, które do walki zbrojnej nie są zobowiązane. Niemniej jednak islam docenia wysiłek kobiet, ponoszących trudy na drodze Boga, prowadzącej człowieka do osiągnięcia szczęśliwego życia w niebie. Owym wysiłkiem,

\footnotetext{
64 Dekret królewski zakazujacy prowadzenia samochodu kobietom, wydany został w 1990 roku. Istnieją interpretacje, że prowadzenie samochodu przez kobietę, negatywnie wpływa na zdrowie jej jajników oraz miednicy i może być problemem przy ciąży oraz porodzie. Saudyjscy specjaliści religijni uważają także, że zgodna na prowadzenie samochodów przez kobiety, doprowadzi do zwiększenia liczby homoseksualistów i spadku liczby dziewic. Por. Zakaz prowadzenia samochodu przez Saudyjki to kwestia polityczna [online], [dostępne 28.07.2015] w World Wide Web http://wiadomosci. onet.pl/swiat/zakaz-prowadzenia-samochodu-przez-saudyjki-to-kwestia-polityczna/ m6plt.

${ }^{65} \mathrm{~W}$ pierwotnym okresie kształtowania się islamu, dżihad był rozumiany jako działalność na rzecz islamu oraz nakłanianie pogańskich Arabów, nieuznających religii objawionych (a więc oprócz żydów i chrześcijan) na przyjęcie islamu.

66 Por. M. Klöcker, M., U. Tworuschka, Etyka..., dz. cyt., s. 65.

67 Por. J. Danecki, Kultura islamu. Słownik, Warszawa 1997, s. 66.
} 
podejmowanym niemal przez każdą muzułmankę jest niesienie trudu ciąży, porodu, a następnie karmienia i wychowania potomstwa na dobrych oraz posłusznych Bogu obywateli. Kobieta stając się matką musi nieustannie walczyć ze swoimi słabościami, przede wszystkim fizycznymi, mężnie znosząc niewygody stanu ciąży w imię wyższych wartości. I chociaż maż jest zobowiązany pomagać żonie i ją wspierać, nie zdejmie z niej największego wysiłku, jakim jest poród.

\section{Praca zawodowa kobiet}

Wspomniane zostało, że odpowiedzialność materialną za utrzymanie odpowiedniego poziomu życia rodziny, ponosi mężczyzna. $Z$ tego powodu tradycja islamu nie obarczała obowiązkiem pracy zawodowej kobiet, uznając, że spoczywa na niej i tak duża odpowiedzialność za prowadzenie domu i wychowywanie dzieci. Obraz kobiety „kury domowej” obowiązywał przez wiele stuleci w społeczeństwie muzułmańskim. Przyjmowany był za normę i naturalną powinność kobiet, zresztą do dziś taki model organizacji życia rodzinnego obowiązuje w wielu miejscach na Bliskim Wschodzie. Jednak wszechobecne dążenie do równouprawnienia kobiet i mężczyzn, zaznaczyło także swoją obecność w tradycji islamu, powodując konieczność wypracowania stanowiska islamu, dotyczącego zawodowej pracy kobiet.

Prawo islamu zezwala kobiecie podejmować pracę zarobkową, przy jednoczesnym wprowadzeniu pewnych zastrzeżeń i regulacji. Kobieta nie może doprowadzić do zaniedbania rodziny oraz obowiązków domowych. Z tego powodu to właśnie mąż musi wyrazić zgodę na podjęcie pracy zawodowej przez kobietę. Zasadniczo, w myśl reguł prawa koranicznego, wybór pracy zawodowej, jak również miejsca pracy nie powinien narażać muzułmanki na kontakty z mężczyznami. Aczkolwiek obecnie nie zwraca się już tak bardzo uwagi na ten postulat, także w krajach o dominacji islamu ${ }^{68}$. Także kobiety muzułmanki coraz częściej chcą podejmować pracę zawodową, aby

\footnotetext{
${ }^{68}$ Przykładem całkowitej integracji kobiet i mężczyzn w miejscu pracy niech będzie turecka redakcja gazety ZAMAN, w której wspólnie w jednym pokoju redakcyjnym, przy sąsiednich biurkach pracują kobiety i mężczyźni.
} 
móc realizować własne ambicje zawodowe i potrzebę pracy na rzecz społeczności, w której żyją.

Należy pamiętać, że coraz więcej Arabek jest kobietami wykształconymi, legitymującymi się dyplomami uznanych na świecie uniwersytetów. Dlatego coraz częściej są prężnie działającymi bizneswomen. Również znaczna grupa kobiet muzułmanek pracuje w uniwersytetach, prowadząc badania naukowe oraz działalność dydaktyczną. Muzułmanki podejmują pracę także w innych dziedzinach na rynku pracy: od najpopularniejszych, typowo damskich zajęć jak nauczycielka albo lekarz po stanowcze panie prezes oraz kobiety prowadzące własną działalność gospodarczą. Przyczyn podejmowania pracy zawodowej można wymienić wiele, ale dwie wydają się najistotniejsze. Pierwszą stanowią względy ekonomiczne, zwłaszcza w realiach europejskich, trudno jest realizować ideał muzułmańskiego małżeństwa, w którym na dom pracuje tylko mężczyzna. Owszem na taką ekstrawagancję i wygodę może sobie pozwolić zaledwie niewielki procent muzułmanów, zazwyczaj prowadzących rozległe interesy międzynarodowe. Drugą przyczyną jest pragnienie kobiety do realizowania własnej ambicji zawodowej. Oczywiście wychowanie dzieci oraz prowadzenie domu, może dawać wiele radości, niemniej jednak w długiej perspektywie ograniczania się tylko do wykonywania prac domowych, może prowadzić do depresji i całkowitego zniechęcenia. Co w konsekwencji negatywnie odciśnie się na relacjach rodzinnych.

W świetle powyższej analizy można stwierdzić, że pozycja kobiety w islamie ma swoją rangę i znaczenie. Kobieta jest ochraniana oraz ceniona za osobowość, określając jej prawa i obowiązki, a także wyznacza jej pozycję w społeczeństwie. Powyższe przykłady ukazują kobietę jako posiadającą kwalifikacje do wykonywania każdego rodzaju pracy. Kobieta nie jest zobowiązana do walki zbrojnej na drodze dżihadu ${ }^{69}$, ale islam jej tego nie zabrania. Jest to wymowny aspekt równouprawnienia kobiet i mężczyzn proponowany przez islam.

69 Dżihad ozn. dosłownie wysiłek, zwalczanie zła w sobie, szerzenie wiary w Boga, budowanie szpitali, szkolnictwo, itp. W praktyce sprowadza się do walki zbrojnej. Por. R. Tokarczuk, Współczesne kultury prawne, Kraków 2005, s. 227 - 228. 


\section{Streszczenie}

Kobieta wislamie. Muzułmańskifeminizm? - Artykuł podejmuje próbę analizy miejsca i funkcji kobiety w społeczności muzułmańskiej. Islam wyraźnie definiuje obowiązki ludzi względem Boga i między sobą. Kobieta została stworzona przez Boga, a jej szczególnym zadaniem jest urodzenie i wychowanie dzieci. Religia narzuca określone zachowanie kobiecie, wyrażone w ubiorze oraz stosowanymzachowaniu, którego najwymowniejszym przejawem jest chrakterystyczny dla kultury muzułmańskiej damski strój. Dominująca od wieków struktura społeczeństwa patriarchalnego w islamie, stałą się przyczyną zmian w świadomości kobiet. W XX wieku zaczęły powstawać ruchy kobiece, będące początkiem nurtu feminizmu muzułmańskiego. Feminizm w islamie posiada dwa główne nurty. Feminizm muzułmański dba o równy dostęp kobiet do edukacji, ochrony zdrowia, praw obywatelskich. Feminizm islamski dąży do postrzegania kobiety zgodnie z nauką Koranu.

Woman in islam. Islamic feminism? - The article analyzes woman's functions in the Muslim community. The religion clearly defines obligations of people towards God and towards one another. The woman has been formed by God to bear and feed children, while the man's duty is their care. Religious functions in the family then stem from gender's natural predisposition. Religion imposes specific behavior upon a woman such as prioritizing (family, bringing up children, profession) or moderation in attire, as expressed in the hijab principle. The predominant for ages structure of the patriarchal society in Islam, solid oneself the cause of changes in the women consciousness. Feminine movements began to come into being in XXth century, being the beginning of the current of Muslim feminism. Feminism in Islam has two main streams. Muslim feminism cares about equal access of women to education, health care, civil rights. Islamic feminism tends to perceive women accordance with the teachings of the Koran.

Key words: woman in islam, islamic feminism, marriage, wife, muslim clothes

Aldona Maria Piwko - absolwentka Uniwersytetu Kardynała Stefana Wyszyńskiego w Warszawie, doktor habilitowana nauk teologicznych i religioznawca. Autorka książki Między konserwatyzmem a liberalizmem. Muzutmańskie praktyki religijne $w$ Polsce, a także ponad 50 artykułów naukowych i popularnonaukowych dotyczących islamu oraz haseł encyklopedycznych. Od $2009 \mathrm{r}$. adiunkt Wydziału Teologicznego UKSW w Warszawie, współpracuje z Centrum 
Formacji Misyjnej, Collegium Bobolanum oraz Ośrodkiem Szkoleń Specjalistycznych Straży Granicznej w Lubaniu. Specjalistka w zakresie islamu, kultury, sztuki muzułmańskiej, a także życia społeczno-politycznego regionu Bliskiego Wschodu i Maghrebu. Członkini: Komitetu ds. Dialogu z Religiami Niechrześcijańskimi Rady ds. Dialogu Międzyreligijnego Konferencji Episkopatu Polski oraz Rady Wspólnej Katolików i Muzułmanów, a także Komitetu Głównego Misyjnej Olimpiady Znajomości Afryki, jak również Międzyinstytutowego Zespołu Badań nad Migracjami Wydziału Nauk Historycznych i Społecznych UKSW. Współautorka programu kształcenia dla kierunku religioznawstwo na UKSW. Gościnne wykłady prowadziła w Polskiej Akademii Nauk.

\section{Bibliografia:}

Abu-Rub H., Zabża B., Status kobiety w islamie, Wrocław 2002.

Amin Q., The Liberation of Women and the New Woman, b.m.w. 2000.

Bobako M., Feminizm islamski. Niechciane dziecko islamu politycznego [online], [dostępne 28.07.2015] w World Wide Web http://www.praktykateoretyczna.pl/czasopismo/ feminizm-islamski-niechciane-dziecko-islamu-politycznego/.

Bogus I., Najstynniejsi projektanci ubiora muzułmanki, „Dziennik” 2009, nr 150 (971), s. 24.

Burkini zakazane. Muzułmanki protestuja [online], [dostępne 20.07.2010] w Word Wide Web http://www.iwoman.pl/na-serio/inews/burkini;zak azne;muzulmanki;protestuja,254,0,529406.html

Brzezińska J., Islam i feminizm? Ruch kobiet w Egipcie na rzecz róznouprawnienia płci, „Acta Universitatis Lodziensis. Folia Sociologica” 2011, nr 39, s. $129-148$.

Danecki J., Kultura islamu. Słownik, Warszawa 1997.

Dziekan M., Dzieje kultury arabskiej, Warszawa 2008.

Gaudefroy-Demombynes M., Narodziny islamu, Warszawa 1988.

Heath J., The Scimitar and the Veil: Extraordinary Women of Islam, Mahwah 2004.

Ideals and role models for women in Qur'an, Hadith and Sirah [online], [dostępne 3.01.2013] w World Wide Web http://islamic.org.uk/womright2. html.

Klöcker M., Tworuschka M., U., Etyka wielkich religii, Warszawa 2002.

Kobiece włosy a religia [online], [dostępne 20.07.2010] w World Wide Web http://www.banzaj.pl/Kobiece-wlosy-a-religia-2383.html.

Kopaliński W., Słownik mitów i tradycji kultury, t. II, Warszawa 2007. 
Koran z języka arabskiego przełożył $i$ komentarzem opatrzył Józef Bielawski, Warszawa 2007.

Machut-Mendecka E., Kobieta bez zasłony. Muzutmanka $w$ świetle wiary i kultury, w: Być kobieta w Oriencie, red. D. Chmielowska, B. Grabowska, Warszawa 2008, s. 18-33.

Machut-Mendecka E., Świat tradycji arabskiej, Warszawa 2005.

Machut-Mendecka E., Świetlista twarz muzutmanki, „Znak” 1998, nr 1 (512), s. 28-36.

Malinowska E., Feminizm europejski, demokracja parytetowa a polski ruch kobiet, Łódź 2002.

Milczarek T., Polska Tatarka w świecie i $w$ domu, „Życie Tatarskie” 2001 nr 7, s. 8.

Nalborczyk A., Czy istnieje strój kobiety muzutmańskiej?, w: Szata oddaje ludzkie obyczaje, czyli o strojach ludów Azji i Afryki, J. Jurewicz, J. Rogala (red.), Warszawa 2008, s. 61-71.

Nalborczyk A., Współczesna sytuacja kobiet muzułmańskich, w: Nie bój się islamu. Leksykon dla dziennikarzy, A. Marek, A. Nalborczyk (red.), Warszawa 2005, s. 71-72.

Nasr S. H., Ideei wartości islamu, Warszawa 1988.

Polska firma na targach $w$ Dubaju [online], [dostępne 21.07.2010] w World Wide Web http://www.bielizna.home.pl/index.php?mpa=500\&id=70.

Szymański E., Zwyczaje, obrzędy i symbole religijne w islamie, w: J. Keller, W. Kotański (red.), Zwyczaje, obrzędy i symbole religijne, Warszawa 1974, s. 500.

Tarlo E., Visibly Muslim: Fashion, Politics, Faith, Oxford 2012.

Tokarczuk R., Współczesne kultury prawne, Kraków 2005.

Tworuschka M., U., Islam, Warszawa 2005.

Tworuschka M., U., Religie świata - Islam, Warszawa 2009.

Walewska D., Rewolucja w świecie mody. Abaja $z$ Harrodsa, „Rzeczpospolita” [online], [dostępne 13.07.2010] w World Wide Web http://www.rp.pl/ artykul/508187_Rewolucja_w_swiecie_mody__abaja_z_Harrodsa.html Wąs A., Islam a demokracja [online], [dostępne 28.07.2015] w World Wide Web http://religie.wiara.pl/doc/472198.Islam-a-demokracja.

Zakaz prowadzenia samochodu przez Saudyjki to kwestia polityczna [online], [dostępne 28.07.2015] w World Wide Web http://wiadomosci.onet.pl/swiat/ zakaz-prowadzenia-samochodu-przez-saudyjki-to-kwestia-polityczna/ m6plt.

Zyzik M., Małżeństwo w prawie muzutmańskim, Warszawa 2003. 